\title{
Transient Dominant Selection for the Modification and Generation of Recombinant Infectious Bronchitis Coronaviruses
}

\author{
Maria Armesto, Rosa Casais, Dave Cavanagh, and Paul Britton
}

\begin{abstract}
We have developed a reverse genetics system for the avian coronavirus infectious bronchitis virus (IBV) in which a full-length cDNA corresponding to the IBV genome is inserted into the vaccinia virus genome under the control of a T7 promoter sequence. Vaccinia virus as a vector for the full-length IBV cDNA has the advantage that modifications can be introduced into the IBV cDNA using homologous recombination, a method frequently used to insert and delete sequences from the vaccinia virus genome. Here we describe the use of transient dominant selection as a method for introducing modifications into the IBV cDNA. We have used it successfully for the substitution of specific nucleotides, deletion of genomic regions, and the exchange of complete genes. Infectious recombinant IBVs are generated in situ following the transfection of vaccinia virus DNA containing the modified IBV cDNA into cells infected with a recombinant fowlpox virus expressing T7 DNA-dependent RNA polymerase.
\end{abstract}

Key words: transient dominant selection (TDS); vaccinia virus; infectious bronchitis virus (IBV); coronavirus; avian; reverse genetics; nidovirus; fowlpox virus; T7 RNA polymerase.

\section{Introduction}

The avian coronavirus, infectious bronchitis virus (IBV), is a highly infectious pathogen of domestic fowl and like other coronaviruses is an enveloped virus that replicates in the cell cytoplasm and contains a single-stranded,

From: Methods in Molecular Biology, vol. 454: SARS- and Other Coronaviruses,

Edited by: D. Cavanagh, DOI: 10.1007/978-1-59745-181-9_19, C Humana Press, New York, NY 
positive-sense RNA genome of $28 \mathrm{~kb}$ for IBV. Molecular analysis of the role of individual genes in pathogenesis of RNA viruses has been advanced by the availability of full-length cDNAs, for the generation of infectious RNA transcripts that can replicate and result in infectious viruses. The assembly of full-length coronavirus cDNAs was hampered owing to regions from the replicase gene being unstable in bacteria. We therefore devised a reverse genetics strategy for IBV involving insertion of the full-length cDNA, under the control of a T7 RNA promoter, into the vaccinia virus genome. This is followed by the in situ recovery of infectious IBV in cells transfected with the vaccinia virus DNA and infected with a recombinant fowlpox virus expressing T7 RNA polymerase (1).

An advantage of using vaccinia virus, in addition to the stability of the IBV cDNA, is the ability to generate modified IBV cDNAs by homologous recombination for the subsequent rescue of recombinant IBVs (rIBVs). We use the vaccinia virus-based transient dominant selection (TDS) recombination method (2) for modifying the IBV cDNA sequence within the vaccinia virus genome (3-5). The method relies on a three-step procedure. In the first step, the modified IBV cDNA is inserted into a plasmid containing a selective marker under the control of a vaccinia virus promoter. In our case we use a plasmid, pGPTNEB193 [Fig. 1; (6)], which contains a dominant selective marker gene, Escherichia coli guanine phosphoribosyltransferase (Ecogpt; (7)), under the control of the vaccinia virus $\mathrm{P}_{7.5 \mathrm{~K}}$ early/late promoter. In the second step, the complete plasmid sequence, containing a region of the IBV cDNA to be modified, is integrated into the IBV sequence in the vaccinia virus genome (Fig. 2). This occurs as a result of a single crossover event involving homologous recombination between the IBV cDNA in the plasmid and the IBV cDNA sequence in the vaccinia virus genome. Recombinant vaccinia viruses (rVV) expressing the Ecogpt gene are selected for resistance against mycophenolic acid (MPA) in the presence of xanthine and hypoxanthine. In the third step, the MPA-resistant rVVs are grown in the absence of MPA selection, resulting in loss of the Ecogpt gene owing to a single homologous recombination event between duplicated sequences, present in the vaccinia virus genome resulting from integration of the plasmid sequence (Fig. 3). During the third step two recombination events can occur, each of them with equal frequency. One event will result in the generation of the original (unmodified) IBV sequence and the other in the generation of an IBV cDNA containing the desired modification.

Infectious rIBVs are generated from the rVV DNA transfected into primary chick kidney $(\mathrm{CK})$ cells previously infected with a recombinant fowlpox virus expressing T7 RNA polymerase [rFPV-T7; $(8)$ ]. In addition, a plasmid, pCiNuc $(\mathbf{1 , 9})$, expressing the IBV nucleoprotein $(\mathrm{N})$, under the control of both the cytomegalovirus (CMV) RNA polymerase II promoter and the T7 RNA promoter, is co-transfected into the CK cells. Expression of T7 RNA polymerase in the presence of the IBV N protein and the rVV DNA, containing the 


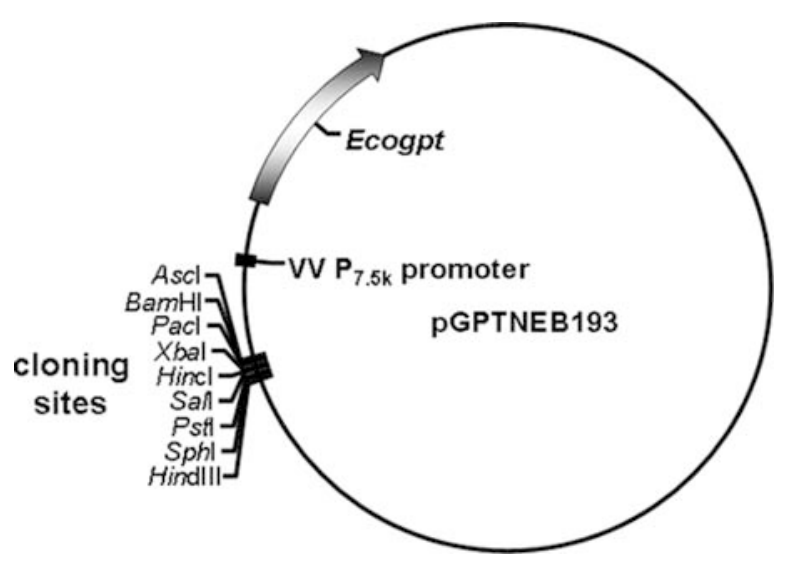

Fig. 1. Schematic diagram of the recombination vector for insertion of genes into a vaccinia virus genome using TDS. Plasmid pGPTNEB193 contains the Ecogpt selection gene under the control of the vaccinia virus early/late $\mathrm{P}_{7.5 \mathrm{k}}$ promoter, a multiple cloning region for the insertion of the sequence to be incorporated into the vaccinia virus genome and the bla gene (not shown) for ampicillin selection of the plasmid in E. coli. For modification of the IBV genome, a sequence corresponding to the region being modified, plus flanking regions of 500 to 800 nucleotides, for recombination purposes is inserted into the multiple cloning sites using an appropriate restriction endonuclease. The plasmid is purified from E. coli and transfected into Vero cells previously infected with a recombinant vaccinia virus containing a full-length cDNA copy of the IBV genome.

full-length IBV cDNA under the control of a $\mathrm{T} 7$ promoter, results in the generation of infectious IBV RNA, which in turn results in the production of infectious rIBVs (Fig. 4).

The overall procedure can be divided into two parts, modification of the IBV cDNA by TDS in recombinant vaccinia viruses and the recovery of infectious rIBV. The generation of the Ecogpt plasmids, based on pGPTNEB193, containing the modified IBV cDNA, is by standard Escherichia coli cloning methods $(10,11)$ and is not described here. General methods for growing vaccinia virus and for using the TDS method for modifying the vaccinia virus genome have been published $(\mathbf{1 2}, 13)$.

\section{Materials}

\subsection{Production of Vaccinia Virus Stocks}

1. BHK-21 maintenance medium: Glasgow-Modified Eagle's Medium (G-MEM; Sigma) containing $2 \mathrm{mM} \mathrm{L-glutamine} \mathrm{(Gibco),} 0.275 \%$ sodium bicarbonate, $1 \%$ 


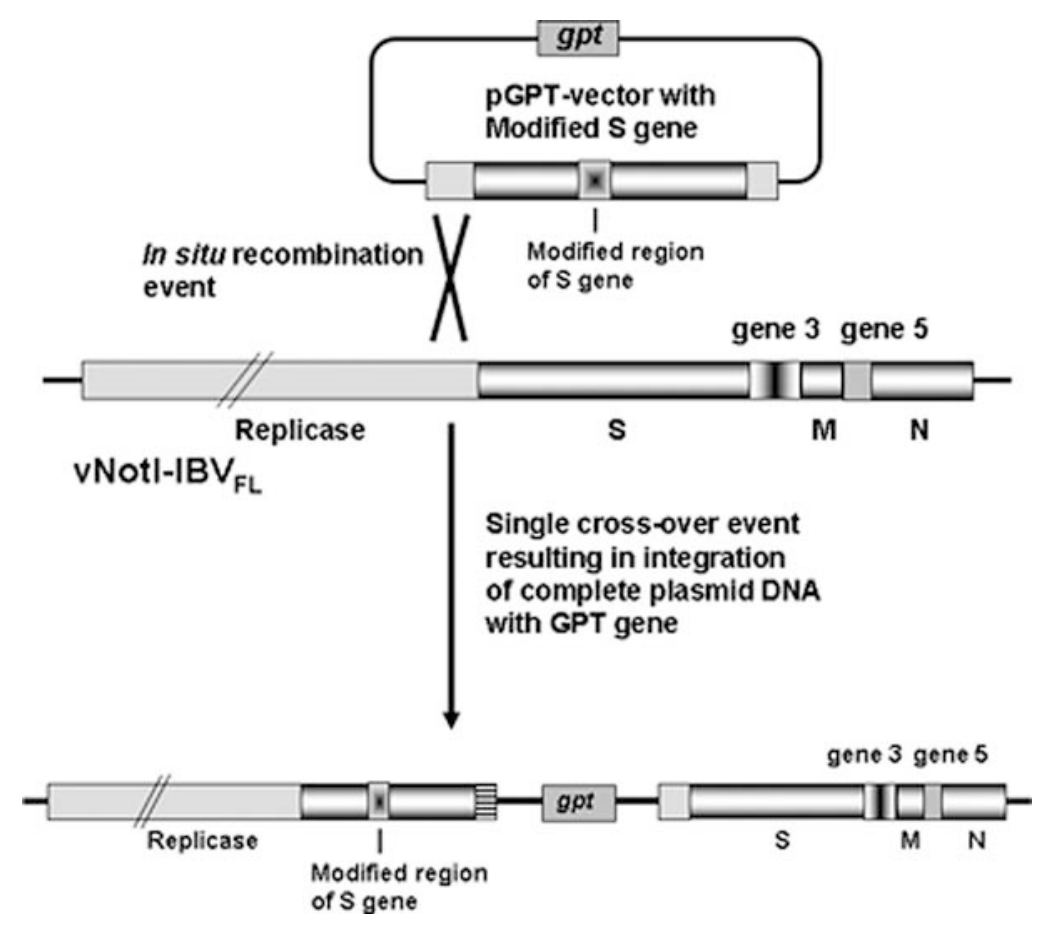

Fig. 2. Schematic diagram demonstrating the TDS method for integrating a modified IBV sequence into the full-length IBV cDNA within the genome of a recombinant vaccinia virus (vNotI-IBV $V_{\mathrm{FL}}$ ). The diagram shows a potential first single-step recombination event between the modified IBV sequence within pGPTNEB193 and the IBV cDNA within vNotI-IBV $\mathrm{FL}_{\mathrm{FL}}$. In order to guarantee a single-step recombination event any potential recombinant vaccinia viruses are selected in the presence of MPA; only vaccinia viruses expressing the Ecogpt gene are selected. The main IBV genes are indicated: the replicase, spike $(\mathrm{S})$, membrane $(\mathrm{M})$, and nucleocapsid $(\mathrm{N})$ genes. The IBV gene 3 and 5 gene clusters that express three and two gene products, respectively, are also indicated. In the example shown a modified region of the $S$ gene is being introduced into the IBV genome.

fetal calf serum (Autogen Bioclear), 0.3\% tryptose phosphate broth (TPB; BDH), $500 \mathrm{U} / \mathrm{ml}$ nystatin (Sigma) and $100 \mathrm{U} / \mathrm{ml}$ penicillin and streptomycin (Sigma).

2. TE buffer: $10 \mathrm{mM}$ Tris-HCl pH 9, $1 \mathrm{mM}$ EDTA.

3. BHK-21 cells.

4. T150 $\left(150-\mathrm{cm}^{2}\right)$ flasks.

5. 50-ml Falcon tubes.

6. Screw-top Eppendorf microfuge tubes.

7. Large Tupperware boxes, Biohazard tape, masking tape.

8. A Beckman CS-15R centrifuge or equivalent. 


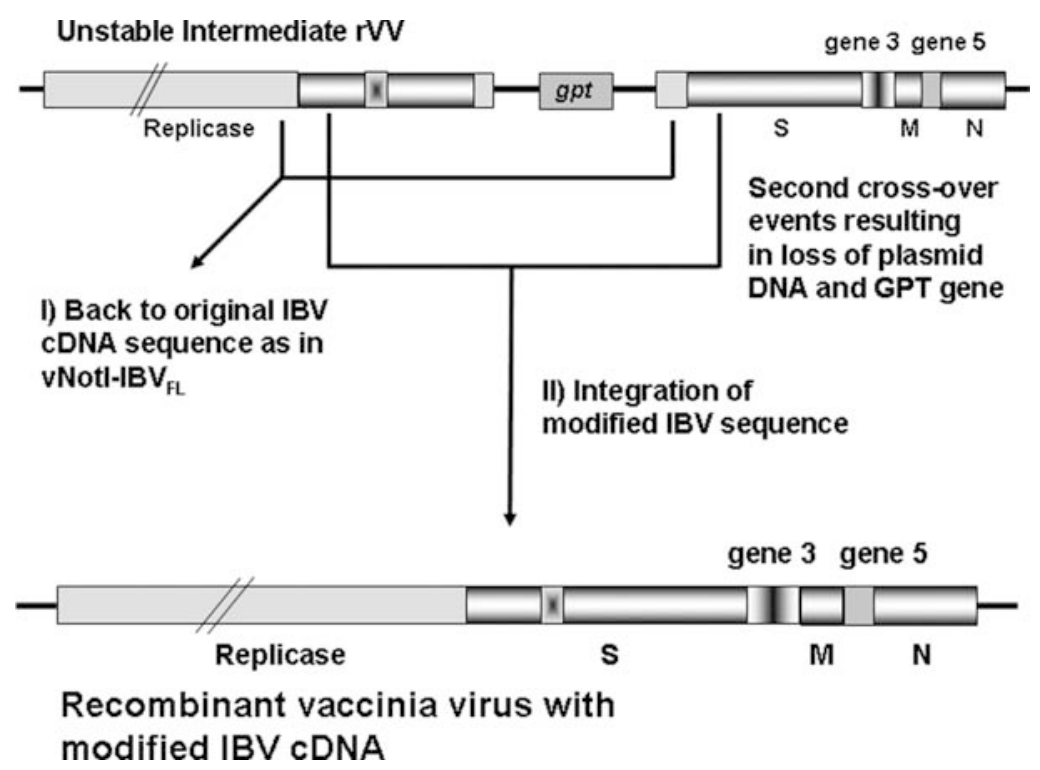

Fig. 3. Schematic diagram demonstrating the second step of the TDS method. Integration of the complete pGPTNEB193 plasmid into the vaccinia virus genome results in an unstable intermediate because of the presence of tandem repeat sequences, in this example the $3^{\prime}$-end of the replicase gene, the $\mathrm{S}$ gene, and the $5^{\prime}$-end of gene 3. The second single-step recombination event is induced in the absence of MPA; loss of selection allows the unstable intermediate to lose one of the tandem repeat sequences including the Ecogpt gene. The second step recombination event can result in either: (I) the original sequence of the input vaccinia virus IBV cDNA sequence, in this case shown as a recombination event between the two copies of the $3^{\prime}$-end of the replicase gene, which results in loss of the modified $\mathrm{S}$ gene sequence along with Ecogpt gene; or (II) retention of the modified $\mathrm{S}$ gene sequence and loss of the original $\mathrm{S}$ gene sequence and Ecogpt gene as a result of a potential recombination event between the two copies of the $5^{\prime}$-end of the $\mathrm{S}$ gene sequence. This event results in a modified $\mathrm{S}$ gene sequence within the IBV cDNA in a recombinant vaccinia virus.

\subsection{Infection/Transfection of Vero Cells}

1. Vero cells.

2. Modified Eagle's Medium: 10X (E-MEM; Sigma).

3. $\mathrm{BES}$ (N,N-Bis(2-hydroxyethyl)-2-aminoethanesulfonic acid) cell maintenance medium: 1X E-MEM, 0.3\% TPB, $0.2 \%$ bovine serum albumin (BSA; Sigma), $20 \mathrm{mM}$ BES, $0.21 \%$ sodium bicarbonate, $2 \mathrm{mM} \mathrm{L}$-glutamine, $250 \mathrm{U} / \mathrm{ml}$ nystatin and $100 \mathrm{U} / \mathrm{ml}$ penicillin and streptomycin. 
A
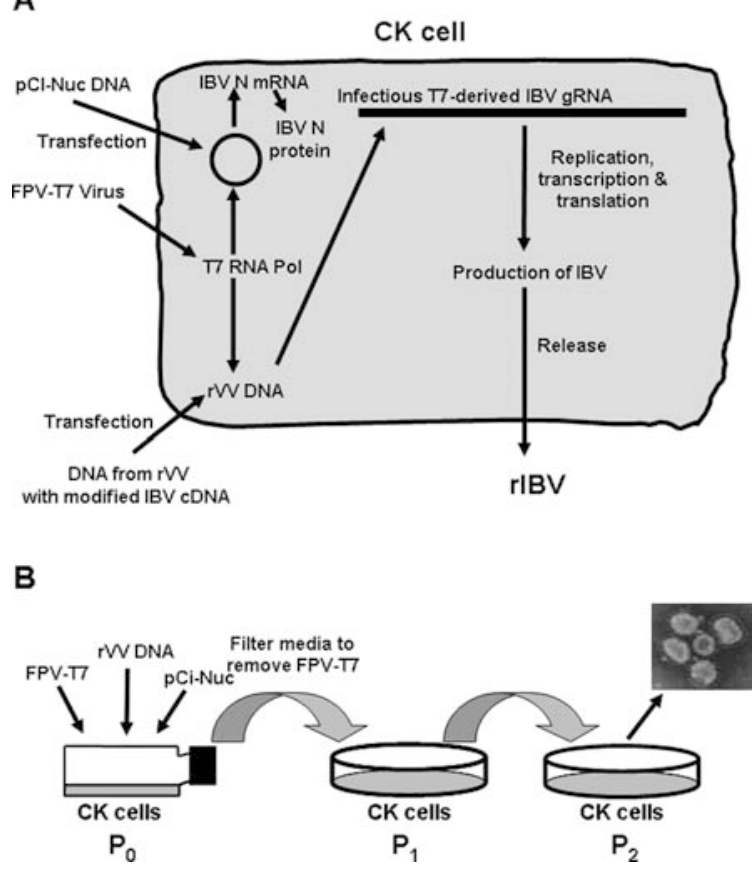

Fig. 4. A schematic representation of the recovery process for obtaining rIBV from DNA isolated from a recombinant vaccinia virus containing a full-length IBV cDNA under the control of a T7 promoter: (A) In addition to the vaccinia virus DNA containing the full-length IBV cDNA under the control of a T7 promoter, a plasmid, pCI-Nuc, expressing the IBV nucleoprotein, required for successful rescue of IBV, is transfected into CK cells previously infected with a recombinant fowlpox virus, FPV-T7, expressing T7 RNA polymerase. The T7 RNA polymerase results in the synthesis of an infectious RNA from the vaccinia virus DNA that consequently leads to the generation of infectious IBV being released from the cell. (B) Any recovered rIBV present in the media of $\mathrm{P}_{0} \mathrm{CK}$ cells is used to infect $\mathrm{P}_{1} \mathrm{CK}$ cells. The medium is filtered though a $0.22-\mu \mathrm{m}$ filter to remove any FPV-T7 virus. IBV-induced CPE is normally observed in the $\mathrm{P}_{1} \mathrm{CK}$ cells following a successful recovery experiment. Any rIBV is passaged a further two times, $\mathrm{P}_{2}$ and $\mathrm{P}_{3}$, in CK cells. Total RNA is extracted from the $\mathrm{P}_{1}$ to $\mathrm{P}_{3} \mathrm{CK}$ cells and the IBV-derived RNA analyzed by RT-PCR for the presence of the required modification.

4. 2X E-MEM medium: E-MEM (2X), $10 \%$ fetal calf serum, $0.35 \%$ sodium bicarbonate, $4 \mathrm{mM}$ L-glutamine, $1000 \mathrm{U} / \mathrm{ml}$ nystatin, and $200 \mathrm{U} / \mathrm{ml}$ penicillin and streptomycin.

5. Six-well plates.

6. OPTIMEM medium (Invitrogen).

7. Lipofectin (Invitrogen). 
8. MXH solution: separate stocks of: (1) mycophenolic acid (MPA; Sigma) $10 \mathrm{mg} / \mathrm{ml}$ in $0.1 \mathrm{~N} \mathrm{NaOH}$, (2) xanthine (Sigma) $10 \mathrm{mg} / \mathrm{ml}$ in $0.1 \mathrm{~N} \mathrm{NaOH}$ (heated at $37^{\circ} \mathrm{C}$ to dissolve), and (3) hypoxanthine (Sigma) $10 \mathrm{mg} / \mathrm{ml}$ in $0.1 \mathrm{~N} \mathrm{NaOH}$.

9. Ecogpt selection medium: Add $250 \mu \mathrm{l}$ of MPA, $2.5 \mathrm{ml}$ of xanthine and $149 \mu \mathrm{l}$ of hypoxanthine to $50 \mathrm{ml}$ of prewarmed 2X EMEM medium. Add $50 \mathrm{ml}$ of $2 \%$ lowmelting-point agarose (keep in a water bath at $42^{\circ} \mathrm{C}$ ) to the $2 \mathrm{X}$ EMEM containing MPA, xanthine, and hypoxanthine and mix well before adding it to vaccinia virus infected cells (see Note 7).

10. Screw-top Eppendorf microfuge tubes.

11. A Beckman CS-15R centrifuge or equivalent.

\subsection{Selection of MPA Resistant Recombinant Vaccinia Viruses (gpt ${ }^{+}$Phenotype)}

1. Vero cell monolayers in six-well plates.

2. PBSa solution: $172 \mathrm{mM} \mathrm{NaCl}, 3 \mathrm{mM} \mathrm{KCl}, 10 \mathrm{mM} \mathrm{Na}_{2} \mathrm{HPO}_{4}$, and $2 \mathrm{mM} \mathrm{KH}_{2} \mathrm{PO}_{4}$ $\mathrm{pH} 7.2$.

3. $1 \mathrm{X}$ E-MEM.

4. Ecogpt selection medium containing 1\% low-melting agarose (see Note 7).

5. 1X E-MEM containing $1 \%$ low-melting agarose and $0.01 \%$ neutral red.

\subsection{Selection of MPA-Sensitive Recombinant Vaccinia Viruses (Loss of gpt ${ }^{+}$Phenotype)}

Two or three of the plaque purified $\mathrm{gpt}^{+} \mathrm{rVVs}$ are used for generation of new rVVs in the absence of MPA selection medium to generate viruses with a $\mathrm{gpt}^{-}$ phenotype.

1. Vero cell monolayers in six-well plates.

2. PBSa.

3. 1X E-MEM

4. 1X E-MEM containing $1 \%$ low-melting agarose (see Note 7).

5. $1 \mathrm{X}$ E-MEM containing $1 \%$ low-melting agarose and $0.01 \%$ neutral red (see Note 7).

6. Ecogpt selection medium containing 1\% low-melting agarose (see Note 7).

\subsection{Screening of Recombinant Vaccinia Viruses}

Small stocks of the plaque-derived rVVs have to be produced for extraction of DNA for screening purposes. The vaccinia DNA is used as a template for PCR and sequence analysis to check for the presence of the modified sequence and confirmation that the Ecogpt gene has been lost. 
1. Vero cell monolayers in six-well plates.

2. $1 \mathrm{X}$ BES medium.

3. PBSa.

4. Freshly prepared proteinase $\mathrm{K}$ (Sigma; $10 \mathrm{mg} / \mathrm{ml})$ in $\mathrm{H}_{2} \mathrm{O}$.

5. $2 \mathrm{X}$ proteinase $\mathrm{K}$ buffer: $200 \mathrm{mM}$ Tris/ $\mathrm{HCl} \mathrm{pH} \mathrm{7.5,} 10 \mathrm{mM}$ EDTA, $0.4 \%$ SDS, $400 \mathrm{mM} \mathrm{NaCl}$.

6. Phenol-chloroform (Amresco), chloroform (BDH), and absolute ethanol (BDH).

7. $70 \%$ ethanol.

8. Bench top microfuge.

\subsection{Vaccinia Virus Purification}

Vaccinia virus DNA for a recovery of IBV requires partial purification of the rVV through a sucrose cushion.

1. 50-ml Falcon tubes.

2. TE buffer.

3. Filtered $30 \%$ sucrose (w/v) in $1 \mathrm{mM}$ Tris/ $\mathrm{HCl} \mathrm{pH} 9$.

4. A Beckman CS-15R centrifuge or equivalent.

5. Superspin 630 rotor and Sorvall OTD65B ultracentrifuge or equivalent.

\subsection{Extraction of Vaccinia Virus DNA}

1. Freshly prepared proteinase $\mathrm{K}$ (Sigma; $10 \mathrm{mg} / \mathrm{ml})$ in $\mathrm{H}_{2} \mathrm{O}$.

2. $2 \mathrm{X}$ proteinase $\mathrm{K}$ buffer: $200 \mathrm{mM}$ Tris/ $\mathrm{HCl} \mathrm{pH} 7.5,10 \mathrm{mM}$ EDTA, $0.4 \%$ SDS, $400 \mathrm{mM} \mathrm{NaCl}$.

3. 15-ml Falcon tubes.

4. Sodium acetate $3 \mathrm{M}$.

5. Phenol-chloroform, chloroform, absolute ethanol, and $70 \%$ ethanol.

6. A Beckman CS-15R centrifuge or equivalent.

\subsection{Analysis of Vaccinia Virus DNA by Pulse Field Agarose Gel Electrophoresis}

1. 10X TBE buffer: $1 \mathrm{M}$ Tris, $0.9 \mathrm{M}$ boric acid $\mathrm{pH} 8$, and $10 \mathrm{mM}$ EDTA.

2. Agarose (Biorad, pulsed field certified ultrapure DNA-grade agarose).

3. DNA markers (e.g., 8-48 kb markers, Biorad).

4. Ethanol, ethidium bromide $(0.5 \mathrm{mg} / \mathrm{ml}), \mathrm{MQ}$ water.

5. CHEF-DR ${ }^{\circledR}$ II pulse field gel electrophoresis (PFGE) apparatus (Biorad).

6. 6X sample loading buffer: $62.5 \%$ glycerol, $62.5 \mathrm{mM}$ Tris- $\mathrm{HCl} \mathrm{pH} \mathrm{8,} 125 \mathrm{mM}$ EDTA and $0.06 \%$ bromophenol blue (BDH).

7. Microwave oven, sealed plastic container to hold gel, orbital shaker, and water bath 


\subsection{Preparation of rFP-T7 Stock Virus}

1. CEF growth medium: 1X 199 Medium with Earle's Salts, 0.3\% TPB, $8 \%$ new born calf serum (NBCS), $0.225 \%$ sodium bicarbonate, $2 \mathrm{mM}$ L-glutamine, 100 $\mathrm{U} / \mathrm{ml}$ penicillin, $100 \mathrm{U} / \mathrm{ml}$ streptomycin and $500 \mathrm{U} / \mathrm{ml}$ nystatin.

2. CEF maintenance medium: as above but containing $2 \%$ NBCS.

3. CEF cells.

4. T75 $\left(75-\mathrm{cm}^{2}\right)$ flasks.

6. A Beckman CS-15R centrifuge or an equivalent centrifuge.

\subsection{Infection CK Cells with rFPV-T7}

1. CK cell maintenance medium: $1 X$ BES medium: BES (N,N-Bis(2-hydroxyethyl)2-aminoethanesulfonic acid) cell maintenance medium: 1X E-MEM, 0.3\% TPB, $0.2 \%$ bovine serum albumin (BSA; Sigma), $20 \mathrm{mM} \mathrm{BES,} 0.21 \%$ sodium bicarbonate, $2 \mathrm{mM}$ L-glutamine, $250 \mathrm{U} / \mathrm{ml}$ nystatin, and $100 \mathrm{U} / \mathrm{ml}$ penicillin and streptomycin.

2. CK cells.

3. 60-mm dishes

4. PBSa.

5. Stock rFPV-T7 virus.

\subsection{Transfection of Vaccinia Virus DNA into CK Cells}

1. OPTIMEM 1 with GLUTAMAX-1 (Invitrogen).

2. Lipofectin reagent (Invitrogen).

3. Stock rFPV-T7 virus.

4. The rVV DNA as prepared in Section 3.7, step 2.

5. Plasmid pCi-Nuc, which contains IBV nucleoprotein under the control of the CMV and $\mathrm{T} 7$ promoters.

6. Millex ${ }^{\circledR}$ GP $0.22-\mu m$ syringe-driven filters (Millipore).

\subsection{Serial Passage of rIBVs}

1. CK cell maintenance medium: 1X BES medium (as in Section 2.2.1, step 3).

2. CK cells.

3. 60-mm dishes.

4. PBSa.

\section{Methods}

\subsection{Production of Vaccinia Virus Stocks}

1. Freeze-thaw the vaccinia virus stocks three times $\left(37^{\circ} \mathrm{C} / \mathrm{dry}\right.$ ice $)$ and sonicate for 2 min using a cup form sonicator (Heat Systems Ultrasonic Inc., Model W-375), continuous pulse at 70\% duty cycle, seven-output control (see Notes 1-4). 
2. Add G-MEM to the sonicated virus and infect twenty T150 flasks of confluent monolayers of BHK-21 cells using $2 \mathrm{ml}$ of the diluted vaccinia virus per flask at a MOI of $0.1-1$. Incubate the infected cells for $1 \mathrm{~h}$ at $37^{\circ} \mathrm{C}$ and $5 \% \mathrm{CO}_{2}$.

3. Add $20 \mathrm{ml}$ of prewarmed $\left(37^{\circ} \mathrm{C}\right) \mathrm{G}-\mathrm{MEM}$ and incubate the infected cells at $37^{\circ} \mathrm{C}$ and $5 \% \mathrm{CO}_{2}$ until the cells show an advanced CPE (normally about 2-3 days). At this stage the cells should easily detach from the plastic.

5. Either continue to step 6 or freeze the flasks at $-20^{\circ} \mathrm{C}$ until use.

6. If prepared from the frozen state the flasks have to be defrosted by leaving them at room temperature for $15 \mathrm{~min}$ and then at $37^{\circ} \mathrm{C}$ until the medium over the cells has thawed.

7. Tap the flasks to detach the cells from the plastic, using a cell scraper if necessary.

8. Transfer the medium containing the cells to 50-ml Falcon tubes and centrifuge at $750 \times g$ for $15 \mathrm{~min}$ at $4{ }^{\circ} \mathrm{C}$ to pellet the cells.

9. Discard the supernatant (99\% of vaccinia virus is cell-associated) and resuspend the cells in $2 \mathrm{ml}$ of TE buffer. This preparation can be used for a working stock of virus (follow point 10) or for further purification of the virus for extraction of DNA.

10. Aliquot the resuspended cells in 1-ml aliquots in screw top microfuge tubes and store at $-70^{\circ} \mathrm{C}$ until required.

11. Determine the titer of the virus stock using Vero cells before use. The titer should be within the order of $10^{8-9} \mathrm{PFU} / \mathrm{ml}$.

\subsection{Infection/Transfection of Vero Cells}

1. Infect six-well plates of $70 \%$ confluent monolayers of Vero cells with the rVV at an MOI of 0.2. Use two independent wells per recombination. (see Notes 1-4)

2. Incubate at $37^{\circ} \mathrm{C} 5 \% \mathrm{CO}_{2}$ for $2 \mathrm{~h}$ in to allow the virus to infect the cells.

3. After $1 \mathrm{~h}$ of incubation, prepare the following solutions for transfection: (a) Solution A: For each transfection: Dilute $5 \mu \mathrm{g}$ of modified pGPTNEB193 (containing the modified IBV cDNA) in $1.5 \mathrm{ml}$ of OPTIMEM medium. (b) Solution B: Dilute $12 \mu \mathrm{l}$ of Lipofectin in $1.5 \mathrm{ml}$ of OPTIMEM for each transfection.

4. Incubate solutions A and B separately for $30 \mathrm{~min}$ at room temperature; then mix the two solutions and incubate the mixture at room temperature for $15 \mathrm{~min}$.

5. During the $15 \mathrm{~min}$, remove the inoculum from the infected cells and wash the cells twice with OPTIMEM.

6. Add $3 \mathrm{ml}$ of the transfection mixture (solutions $\mathrm{A}+\mathrm{B}$ ) to each well.

7. Incubate for $60-90 \mathrm{~min}$ at $37^{\circ} \mathrm{C}, 5 \% \mathrm{CO}_{2}$.

8. Remove the transfection mixture from the cells and replace it with $3 \mathrm{ml}$ of BES medium.

9. Incubate the transfected cells overnight at $37^{\circ} \mathrm{C}, 5 \% \mathrm{CO}_{2}$.

10. The following morning add the MXH components, MPA $12.5 \mu$, xanthine $125 \mu \mathrm{l}$, and hypoxanthine $7.4 \mu \mathrm{l}$, directly to each well.

11. Incubate the cells at $37^{\circ} \mathrm{C}, 5 \% \mathrm{CO}_{2}$ until they display advanced vaccinia virus induced CPE (normally 2 days). 
12. Harvest the infected/transfected cells into the cell medium of the wells and centrifuge for 3-4 min at $300 \times g$. Discard supernatant and resuspend the pellet in $0.4 \mathrm{ml}$ of $1 \mathrm{X}$ E-MEM.

13. Freeze-thaw the vaccinia virus stocks (see Notes $\mathbf{1 - 4})$ three times $\left(37^{\circ} \mathrm{C} / \mathrm{dry}\right.$ ice) and sonicate for $2 \mathrm{~min}$ using a cup form sonicator (Heat Systems Ultrasonic Inc., Model W-375), continuous pulse at $70 \%$ duty cycle, seven-output control. This will be the stock virus for selection of a rVV containing the intended modification. The virus can be stored at $-20^{\circ}$ or $-70^{\circ} \mathrm{C}$.

\subsection{Selection of MPA-Resistant Recombinant Vaccinia Viruses $\left(G P T^{+}\right.$ Phenotype)}

Isolation of $\mathrm{gpt}^{+} \mathrm{rVVs}$ is by plaque assay on Vero cells.

1. Freeze-thaw the vaccinia virus three times $\left(37^{\circ} \mathrm{C} / \mathrm{dry}\right.$ ice $)$ and sonicate for $2 \mathrm{~min}$ using a cup form sonicator (Heat Systems Ultrasonic Inc., Model W-375), continuous pulse at $70 \%$ duty cycle, seven-output control (see Notes 1-4).

2. Remove the medium from Vero cells in six-well plates and wash the cells twice with PBSa.

3. Prepare $10^{-1}$ and $10^{-2}$ dilutions of the recombinant vaccinia virus in $1 \mathrm{X}$ E-MEM (normally, dilute $150 \mu$ l of virus in $1350 \mu$ l of medium).

4. Remove the PBSa from the Vero cells and add $500 \mu \mathrm{l}$ of the diluted virus per well (assay each dilution in duplicate).

5. Incubate for $1-2 \mathrm{~h}$ at $37^{\circ} \mathrm{C}, 5 \% \mathrm{CO}_{2}$.

6. Remove the inoculum and add $3 \mathrm{ml}$ of the Ecogpt selection medium in $1 \%$ lowmelting agarose overlay (see Note 7).

7. Incubate for 4 days at $37^{\circ} \mathrm{C}, 5 \% \mathrm{CO}_{2}$ and stain the cells by adding $2 \mathrm{ml}$ of $1 \mathrm{X}$ E-MEM containing $1 \%$ agarose and $0.01 \%$ neutral red.

8. Incubate the cells at $37^{\circ} \mathrm{C}, 5 \% \mathrm{CO}_{2}$ for $6 \mathrm{~h}$ and pick ten-well isolated plaques for each recombinant by taking a plug of agarose directly above the plaque. Place the plug of agarose in $400 \mu \mathrm{l}$ of $1 \mathrm{X}$ E-MEM.

9. Perform two further rounds of plaque purification for each selected recombinant vaccinia virus (two or three of the picked plaques from step 8) in the presence of selection medium, as described in steps $1-8$, using a dilution of $10^{-1}$ for each virus.

\subsection{Selection of MPA-Sensitive Recombinant Vaccinia Viruses (Loss of gpt $^{+}$Phenotype)}

1. Take the MPA resistant plaque-purified rVVs and freeze-thaw the virus three times $\left(37^{\circ} \mathrm{C} /\right.$ dry ice) and sonicate for 2 min using a cup form sonicator (Heat Systems Ultrasonic Inc., Model W-375), continuous pulse at $70 \%$ duty cycle, seven-output control (see Notes 1-4). 
2. Remove the medium from Vero cells in six-well plates and wash the cells with PBSa.

3. Prepare $10^{-1}$ and $10^{-2}$ dilutions of the gpt $^{+}$plaque-purified recombinant vaccinia viruses in $1 \mathrm{X}$ E-MEM

4. Remove the PBSa from the Vero cells and add $500 \mu \mathrm{l}$ of the diluted gpt ${ }^{+}$plaquepurified recombinant vaccinia viruses to each well (assay each dilution in duplicate).

5. Incubate the infected Vero cells for $1-2 \mathrm{~h}$ at $37^{\circ} \mathrm{C}, 5 \% \mathrm{CO}_{2}$.

6. Remove the inoculum and add $3 \mathrm{ml}$ of overlay containing $1 \mathrm{X}$ E-MEM and $1 \%$ agarose.

7. Incubate the infected Vero cells for 4 days at $37^{\circ} \mathrm{C}, 5 \% \mathrm{CO}_{2}$ and stain the cells by adding $2 \mathrm{ml}$ of $1 \mathrm{X}$ E-MEM containing $1 \%$ agarose and $0.01 \%$ neutral red. At the end of the day or the following morning, choose approximately ten isolated plaques for each recombinant and resuspend in $400 \mu \mathrm{l}$ of $1 \mathrm{X}$ E-MEM.

8. Plaque purify each recombinant vaccinia virus three times in the absence of selection medium following the same procedure in Section 3.3, as described for plaque purification in presence of selection medium. However, dilutions of $10^{-1}, 10^{-2}$, and $10^{-3}$ are required. Dilution $10^{-1}$ is plated in the presence of Ecogpt selection medium, to identify the presence of any MPA-resistant rVVs. Dilutions $10^{-2}$ and $10^{-3}$ are carried out in the absence of selection medium. Once there is no evidence of MPA-resistant rVVs in the MPA selection controls, it can be assumed that the Ecogpt gene has been lost and the recombinant vaccinia viruses can be screened for the presence of the required modifications and the presence/absence of the Ecogpt gene confirmed.

9. Select several plaques and place the plug of agarose in $400 \mu \mathrm{l}$ of 1 X EMEM.

\subsection{Screening of Recombinant Vaccinia Viruses}

1. Take the plaque-purified rVVs and freeze-thaw three times $\left(37^{\circ} \mathrm{C} /\right.$ dry ice $)$ and sonicate for 2 min using a cup form sonicator (Heat Systems Ultrasonic Inc., Model W-375), continuous pulse at $70 \%$ duty cycle, seven-output control. (see Notes 1-4).

2. Wash the Vero cells with PBSa.

3. Dilute $150 \mu \mathrm{l}$ of the sonicated rVVs in $350 \mu \mathrm{l}$ of $1 \mathrm{X}$ BES medium.

4. Remove the PBSa from the Vero cells and add $500 \mu \mathrm{l}$ of the diluted rVVs.

5. Incubate at $37^{\circ} \mathrm{C}, 5 \% \mathrm{CO}_{2}$ for $1-2 \mathrm{~h}$.

6. Remove the virus inoculum and add $2.5 \mathrm{ml}$ of $1 \mathrm{X}$ BES medium.

7. Incubate the infected Vero cells at $37^{\circ} \mathrm{C}, 5 \% \mathrm{CO}_{2}$ until the cells show signs of vaccinia virus-induced $\mathrm{CPE}$ in about $70-80 \%$ of the Vero cell monolayer (approx. 4 days).

8. Scrape the Vero cells into the medium and centrifuge for $1 \mathrm{~min}$ at $13,000 \mathrm{rpm}$ $(16,000 \times g)$.

9. Discard the supernatants and resuspend the cells in $800 \mu \mathrm{l}$ of $1 \mathrm{X}$ BES medium. 
10. Take $700 \mu \mathrm{l}$ of the resuspended cells as virus stocks and store at $-20^{\circ} \mathrm{C}$.

11. To the remaining $100 \mu \mathrm{l}$ of the resuspended cells add $100 \mu \mathrm{l} 2 \mathrm{X}$ proteinase $\mathrm{K}$ buffer and $2 \mu \mathrm{l}$ of the $10 \mathrm{mg} / \mathrm{ml}$ proteinase $\mathrm{K}$ stock to give a final concentration of $0.1 \mathrm{mg} / \mathrm{ml}$. Gently mix to prevent shearing of the vaccinia virus DNA and incubate at $50^{\circ} \mathrm{C}$ for $2 \mathrm{~h}$ (see Note 5).

12. Add $200 \mu \mathrm{l}$ of phenol-chloroform to the proteinase K-treated samples and mix by inverting the tube five to ten times and centrifuge at $13,000 \mathrm{rpm}(16,000 \times g)$ for $5 \mathrm{~min}$.

13. Take the upper phase (aqueous phase) and repeat step 12 twice more.

14. Add $200 \mu \mathrm{l}$ of chloroform to the upper phase from the final step of 13. Mix well and centrifuge at $13,000 \mathrm{rpm}(16,000 \times \mathrm{g})$ for $5 \mathrm{~min}$.

15. Take the upper phase and precipitate the vaccinia virus DNA by adding 2.5 volumes of absolute ethanol; the precipitated DNA should be visible. Centrifuge the precipitated DNA at 13,000 $(16,000 \times g)$ for $20 \mathrm{~min}$. Discard the supernatant and wash the pelleted DNA with $400 \mu 170 \%$ ethanol.

16. Centrifuge at $13,000 \mathrm{rpm}(16,000 \times g)$ for $10 \mathrm{~min}$, carefully discard the supernatant and remove the last drops of $70 \%$ ethanol using a capillary tip.

17. Resuspend the DNA in $30 \mu \mathrm{l}$ of water, briefly heat the DNA at $50^{\circ} \mathrm{C}$ (with the lid of the Eppendorf tube opened) to remove any remaining ethanol, and store at $4^{\circ} \mathrm{C}$.

18. At this stage the rVV DNA from step 17 is analyzed by PCR and/or sequence analysis for the presence/absence of the Ecogpt gene and for the modifications within the IBV cDNA sequence. The rVVs that have lost the Ecogpt gene and contain the desired IBV modifications are used to produce larger stocks of virus, as described in Section 3.1 (but using smaller amounts) for further analysis and for the preparation of larger stocks of vaccinia virus DNA for recovery of rIBV.

\subsection{Vaccinia Virus Purification}

1. Prepare large batches of vaccinia virus as described in Section 3.1. Ten T150 flasks are normally sufficient (see Notes 1-4).

2. Freeze-thaw the $2-\mathrm{ml}$ aliquots, from Section 3.1 , step 9 , three times $\left(37^{\circ} \mathrm{C} /\right.$ dry ice $)$ and sonicate for $2 \mathrm{~min}$ using a cup form sonicator (Heat Systems Ultrasonic Inc., Model W-375), continuous pulse at 70\% duty cycle, seven-output control.

3. Place the aliquots on ice and then pool identical aliquots in 50-ml Falcon tubes and centrifuge (Beckman CS-15R) at $750 \times g$ for $10 \mathrm{~min}$ at $4{ }^{\circ} \mathrm{C}$ to remove the cell nuclei.

4. Add TE buffer to the supernatants to give a final volume of $13 \mathrm{ml}$.

5. Add $16 \mathrm{ml}$ of the $30 \%$ sucrose solution into a Beckman ultra-clear $(25 \times 89 \mathrm{~mm})$ ultracentrifuge tube and carefully layer $13 \mathrm{ml}$ of the cell lysate from step 4 onto the sucrose cushion. Place the tubes in a superspin 630 rotor.

6. Centrifuge the samples using a Sorvall OTD65B ultracentrifuge with a superspin 630 rotor at $14,000 \mathrm{rpm}(36,000 \times g)$ at $4^{\circ} \mathrm{C}$ for $60 \mathrm{~min}$. 
7. The partially purified vaccinia virus particles form a pellet under the sucrose cushion. After centrifugation carefully remove the top layer (usually pink) and the sucrose layer with a pipette. Wipe the sides of the tube carefully with a tissue to remove any sucrose solution.

8. Resuspend each pellet using $5 \mathrm{ml}$ of TE buffer and store at $-70^{\circ} \mathrm{C}$.

\subsection{Extraction of Vaccinia Virus DNA}

1. Defrost the partially purified vaccinia virus from step 3.6 .8 at $37^{\circ} \mathrm{C}$ and add $5 \mathrm{ml}$ of prewarmed $2 \mathrm{X}$ proteinase $\mathrm{K}$ buffer and $100 \mu \mathrm{l}$ of $10 \mathrm{mg} / \mathrm{ml}$ proteinase $\mathrm{K}$. Incubate at $50^{\circ} \mathrm{C}$ for $2 \mathrm{~h}$ (see Notes 1-4).

2. Add $5 \mathrm{ml}$ of the proteinase $\mathrm{K}$ treated vaccinia virus DNA into two 15 -ml Falcon tubes.

3. Add $5 \mathrm{ml}$ of phenol-chloroform, mix by inverting the tube five to ten times, and centrifuge at $1100 \times g$ for $15 \mathrm{~min}$ at $4{ }^{\circ} \mathrm{C}$. Cut the end of the pipette tips and transfer the upper phase to a clean 15-ml Falcon tube. Repeat this step once more, placing the upper phase in a clean 15-ml Falcon tube. (see Note 5).

4. Add $5 \mathrm{ml}$ of chloroform, mix by inverting the tube five to ten times, and centrifuge at $1100 \times g$ for $15 \mathrm{~min}$ at $4^{\circ} \mathrm{C}$. Transfer $2.5 \mathrm{ml}$ of the upper phase to two clean 15-ml Falcon tubes.

5. Precipitate the vaccinia virus DNA by adding 2.5 volumes of absolute ethanol and 0.1 volumes of $3 \mathrm{M}$ sodium acetate. Centrifuge at $1200 \times g$, at $4{ }^{\circ} \mathrm{C}$ for $30 \mathrm{~min}$. In order to visualize the DNA pellet $2 \mu \mathrm{l}$ of pellet paint (Novagen) per sample can be added before the $3 \mathrm{M}$ sodium acetate, mix, add the ethanol, mix again, and incubate for $2 \mathrm{~min}$ at room temperature before centrifugation.

6. Discard the supernatant and wash the DNA using $10 \mathrm{ml}$ of $70 \%$ ethanol. Leave on ice for $5 \mathrm{~min}$ and centrifuge at $1200 \times \mathrm{g}, 4^{\circ} \mathrm{C}$ for $30 \mathrm{~min}$. Discard the supernatant and remove the last drops of ethanol using a capillary tip. Dry the inside of the tube using a tissue to remove any ethanol.

7. Resuspend the vaccinia DNA in $300 \mu$ l of water and briefly heat at $50^{\circ} \mathrm{C}$ to remove any remaining ethanol. Gently flick the tube until the DNA dissolves. Note: more water may have to be added, depending on the viscosity of the DNA solution.

8. Leave the tubes at $4^{\circ} \mathrm{C}$ overnight. If the pellet has not totally dissolved, add more water.

9. Keep the vaccinia virus DNA at $4^{\circ} \mathrm{C}$. DO NOT FREEZE (see Note 6).

10. Digest $1 \mu \mathrm{g}$ of the DNA with a suitable restriction enzyme in a $20-\mu l$ volume to check the quality of the DNA by pulse field agarose gel electrophoresis.

\subsection{Analysis of Vaccinia Virus DNA by Pulse Field Agarose Gel Electrophoresis}

1. Prepare 2.3 liters of $0.5 \mathrm{X}$ TBE buffer for preparation of the agarose gel and as an electrophoresis running buffer. $100 \mathrm{ml}$ is required for a $12.7 \times 14$-cm agarose gel and 2 liters is required as running buffer. 
Table 1

\section{Standard Conditions for Producing a PFGE Agarose Gel}

\begin{tabular}{lll}
\hline Agarose concentration & \multicolumn{1}{c}{$0.8 \%$} & $1.0 \%$ \\
\hline Buffer & $0.5 \mathrm{X} \mathrm{TBE}$ & $0.5 \mathrm{X} \mathrm{TBE}$ \\
Gel volume & $100 \mathrm{ml}$ & $100 \mathrm{ml}$ \\
Initial pulse time & $0.1 \mathrm{sec}$ & $3.0 \mathrm{sec}$ \\
Final pulse time & $1.0 \mathrm{sec}$ & $30.0 \mathrm{sec}$ \\
Duration & $6-16 \mathrm{~h}$ & $16-20 \mathrm{~h}$ \\
Voltage & $6.0 \mathrm{~V} / \mathrm{cm}$ & $6.0 \mathrm{~V} / \mathrm{cm}$ \\
\hline
\end{tabular}

2. Calculate the concentration of agarose that is needed to analyze the range of DNA fragments. Increasing the agarose concentration decreases the DNA mobility within the gel, requiring a longer run time or a higher voltage. However, a higher voltage can increase DNA degradation and reduce resolution. A $0.8 \%$ agarose gel is suitable for separating DNA ranging between $50-95 \mathrm{~kb}$. A $1 \%$ agarose gel is suitable for separating DNA ranging between 20 and $300 \mathrm{~kb}$.

3. Place the required amount of agarose in $100 \mathrm{ml}$ of $0.5 \mathrm{X} \mathrm{TBE}$, microwave until the agarose is dissolved, and cool to approximately $50^{\circ}-60^{\circ} \mathrm{C}$.

4. Clean the gel frame and comb with MQ water followed by ethanol. Place the gel frame on a level surface, assemble the comb, and pour the cooled agarose into the gel frame. Remove any bubbles using a pipette tip, allow the agarose to set (approx. 30-40 $\mathrm{min}$ ), and store in the fridge until required.

5. Place the remaining $0.5 \mathrm{X}$ TBE buffer into the CHEF-DR ${ }^{\circledR}$ II PFGE electrophoresis tank and switch the cooling unit on. Leave the buffer circulating to cool.

6. Add the sample loading dye to the digested vaccinia virus DNA samples (Section 3.7 , step 10) and incubate at $65^{\circ} \mathrm{C}$ for $10 \mathrm{~min}$.

7. Place the agarose gel in the electrophoresis chamber; load the samples using tips with cut ends (widened bore) and appropriate DNA markers (see Note 5).

8. The DNA samples are analyzed by PFGE at $14^{\circ} \mathrm{C}$ in gels run with a $0.1-1.0$ sec switch time for $16 \mathrm{~h}$ at $6 \mathrm{~V} / \mathrm{cm}$ at an angle of $120^{\circ}$ or with a switch time of $3.0-30.0 \mathrm{sec}$ for $16 \mathrm{~h}$ at $6 \mathrm{~V} / \mathrm{cm}$, depending on the concentration of agarose used. Table 1 summarizes the standard conditions for $0.8 \%$ and $1.0 \%$ agarose gels for PFGE.

9. Following PFGE place the agarose gel in a sealable container with $400 \mathrm{ml}$ of 0.1 $\mu \mathrm{g} / \mathrm{ml}$ ethidium bromide and gently shake for $30 \mathrm{~min}$ at room temperature.

10. Wash the ethidium-stained agarose gel in $400 \mathrm{ml}$ of MQ water by gently shaking for $30 \mathrm{~min}$.

11. Visualize DNA bands using a suitable UV system for analyzing agarose gels. An example of recombinant vaccinia virus DNA digested with the restriction enzyme SalI and analyzed by PFGE is shown in Fig. 5. 


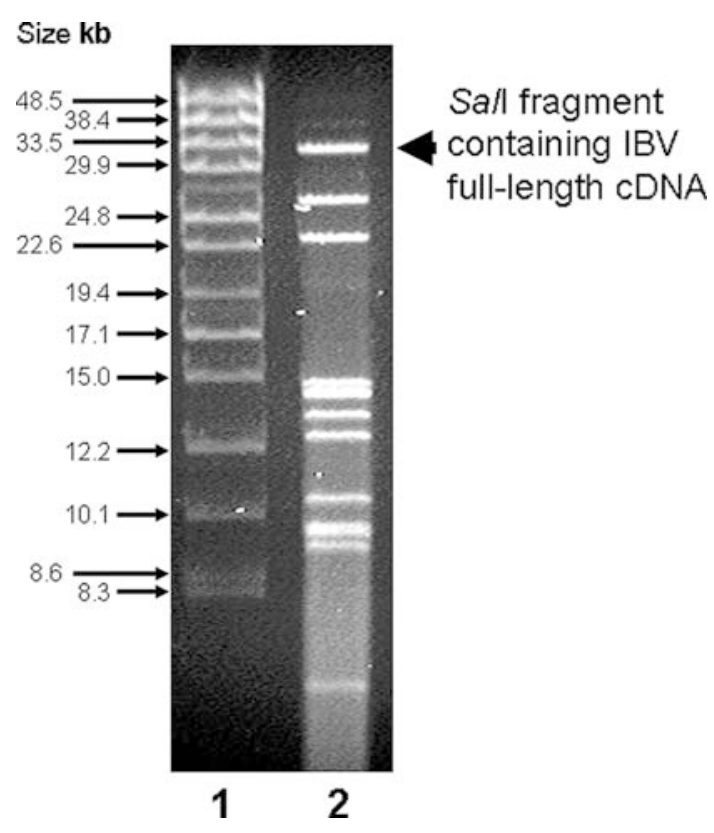

Fig. 5. Analysis of SalI digested vaccinia virus DNA by PFGE. Lane 1 shows DNA markers and Lane 2 the digested vaccinia virus DNA. The IBV cDNA used does not contain a SalI restriction site; therefore the largest DNA fragment $(\sim 31 \mathrm{~kb})$ generated from the recombinant vaccinia virus DNA represents the IBV cDNA with some vaccinia virus-derived DNA at both ends.

\subsection{Preparation of rFP-T7 Stock Virus}

Infectious recombinant IBVs are generated in situ by co-transfection of vaccinia virus DNA, containing the modified IBV cDNA and pCi-Nuc into CK cells previously infected with a recombinant fowlpox virus expressing T7 DNAdependent RNA polymerase. This protocol covers the procedure for infecting primary avian chicken embryo fibroblasts (CEF) cells with a recombinant fowlpox virus (rFPV/T7) expressing the bacteriophage T7 RNA polymerase under the direction of the vaccinia virus $\mathrm{P}_{7.5}$ early-late promoter $(8)$. Preparation of a $200-\mathrm{ml}$ stock of rFPV/T7 uses ten T75 flasks containing confluent monolayers of CEF cells.

1. Remove the culture growth medium from the cells and infect with $2 \mathrm{ml}$ of rFPV/T7 at an MOI of 0.1, previously diluted in CEF maintenance medium.

2. Incubate the infected cells for $2 \mathrm{~h}$ at $37^{\circ} \mathrm{C} 5 \% \mathrm{CO}_{2}$; then without removing the inoculum add $20 \mathrm{ml}$ of CEF maintenance medium. 
3. After 4 days postinfection check for CPE (90\% of the cells should show CPE). Tap the flasks to detach the cells from the plastic and disperse the cells into the medium by pipetting them up and down.

4. Freeze-thaw the cells, as described in Section 3.1, step 1, and centrifuge at $750 \times \mathrm{g}, 4^{\circ} \mathrm{C}$ for $5 \mathrm{~min}$ to remove the cell debris. Store the supernatant containing the virus stock at $-80^{\circ} \mathrm{C}$ until required.

5. Determine the titer of the virus stock using CEF cells. The titer should be on the order of $10^{7} \mathrm{PFU} / \mathrm{ml}$.

\subsection{Infection CK Cells with rFPV-T7}

1. Seed CK cells in $13 \times 60-\mathrm{mm}$ dishes to give a $50 \%$ confluent monolayers on the day after seeding. Normally, for each recovery we prepare twelve dishes, ten replicates for the recovery experiment and two controls, rFPV-T7-infected and mock-infected CK cells.

2. Remove the medium and wash the cells once with PBSa.

3. Infect the cells with rFPV-T7 at an MOI of 10. Add the virus into a final volume of $1 \mathrm{ml}$ of $\mathrm{CK}$ cell maintenance medium per dish.

4. Incubate for $1 \mathrm{~h}$ at $37^{\circ} \mathrm{C}, 5 \% \mathrm{CO}_{2}$, whilst incubating the cells, prepare the solutions as outlined in Section 3.11.

\subsection{Transfection of Vaccinia Virus DNA into CK Cells}

During the infection of CK cells with rFPV-T7 prepare the transfection reaction reagents: rVV DNA, pCi-Nuc, and Lipofectin (Invitrogen). The reagents are added as follows:

1. Prepare the two master solutions: (A) $15 \mathrm{ml}$ OPTIMEM add $100 \mu \mathrm{g}$ of rVV DNA and $50 \mu \mathrm{g}$ of pCi-Nuc. (B) $15 \mathrm{ml}$ OPTIMEM add $300 \mu \mathrm{l}$ of Lipofectin.

2. Incubate solutions $A$ and $B$ at room temperature for $30 \mathrm{~min}$.

3. Mix A and B together and incubate for a further $15 \mathrm{~min}$ at room temperature.

4. Wash the rFPV-T7 infected CK cells twice with OPTIMEM and carefully add $3 \mathrm{ml}$ of the $\mathrm{A}+\mathrm{B}$ transfection mixture to ten of the dishes of the rFPV-T7-infected CK cells. The other two dishes are for the controls described above.

5. Incubate the transfected cells at $37^{\circ} \mathrm{C}, 5 \% \mathrm{CO}_{2}$ for $16 \mathrm{~h}$.

6. Next morning, remove the transfection medium and add $5 \mathrm{ml}$ of fresh BES medium and incubate at $37^{\circ} \mathrm{C}, 5 \% \mathrm{CO}_{2}$.

7. Two days after changing the transfection media, when FPV/IBV-induced CPE is obvious (approx. 50\%), harvest the cell supernatant, place in Eppendorf tubes, centrifuge for $3 \mathrm{~min}$ at $13,000 \mathrm{rpm}(16,000 \times \mathrm{g})$, place it into 5-ml Bijoux tubes, and filter it through a $0.22-\mu \mathrm{m}$ (pore size) filter to remove any rFPV-T7 virus present. 


\subsection{Serial Passage of rIBVs}

To check for the presence of any recovered rIBVs, the medium from the $\mathrm{P}_{0}$ CK cells (Section 3.11, step 7) is passaged three times, $\mathrm{P}_{1}$ to $\mathrm{P}_{3}$, on CK cells (Fig. 4B), checking for any IBV-associated CPE. Total RNA is extracted from the $\mathrm{P}_{1}$ to $\mathrm{P}_{3} \mathrm{CK}$ cells and analyzed for the presence of IBV RNA by specific RT-PCR reactions (see Note 8). For passage $1\left(\mathrm{P}_{1}\right)$ :

1. Seed CK cells in T25 flasks to be confluent monolayers on the day required.

2. Remove the growth medium and wash once with PBSa.

3. Add $1 \mathrm{ml}$ of the filtered medium from the $\mathrm{P}_{0} \mathrm{CK}$ cells (Section 3.11, step 7) to the confluent CK cells and incubate at $37^{\circ} \mathrm{C}, 5 \% \mathrm{CO}_{2}$ for $1 \mathrm{~h}$. Then, without removing the inoculum add $4 \mathrm{ml}$ of BES medium.

4. Check the cells for IBV-associated CPE over the next 2-3 days. When about $50-75 \%$ of the CK cells show a CPE, infect new cells with some of the cell medium as described in steps 1 to 3 . Repeat for serial passages $\mathrm{P}_{2}$ and $\mathrm{P}_{3} \mathrm{CK}$ cells. Filtration of the infected cell medium is not required after $P_{1}$.

5. After $\mathrm{P}_{3}$ any recovered virus is used to prepare a large stock for analysis of the virus genotype and phenotype.

\section{Notes}

1. Vaccinia virus is classified as a category 2 human pathogen and its use is therefore subject to local regulations and rules that have to be followed.

2. Always discard any medium of solution containing vaccinia virus into a $1 \%$ solution of Virkon; leave at least $12 \mathrm{~h}$ before discarding.

3. Flasks of cells infected with vaccinia virus should be kept in large Tupperware boxes, which should be labeled with the word vaccinia and biohazard tape. A paper towel should be put on the bottom of the boxes to absorb any possible spillage.

4. During centrifugation of vaccinia virus infected cells use sealed buckets for the centrifugation to avoid possible spillage.

5. Vaccinia virus DNA is a very large molecule that is very easy to shear; therefore when working with the DNA be gentle and use wide bore tips, cutting the ends off ordinary pipette tips.

6. Always store vaccinia virus DNA at $4^{\circ} \mathrm{C}$; do not freeze the DNA as this leads to degradation of the DNA.

7. $1 \%$ low-melting agarose can be substituted with $1 \%$ agar.

8. There is always the possibility that the recovered rIBV is not cytopathic. In this case, check for the presence of viral RNA by RT-PCR at each passage, starting at $\mathrm{P}_{1}$.

\section{Acknowledgments}

The authors thank Dr. M. Skinner for providing pGPTNEB193. We also thank many colleagues, both past and present, who have been involved in the development of our IBV reverse genetics system. This work was supported 
by the Department of Environment, Food and Rural Affairs (DEFRA) project codes OD1905, OD0712, and OD0717; European Communities specific RTD program Quality of Life and Management of Living Resources QLK2-CT1999-00002; Intervet UK; the British Egg Marketing Board (BEMB); and the Biotechnology and Biological Sciences Research Council (BBSRC) grant No. 201/15836.

\section{References}

1. Casais, R., Thiel, V., Siddell, S. G., Cavanagh, D., and Britton, P. (2001) Reverse genetics system for the avian coronavirus infectious bronchitis virus. J. Virol. 75, 12359-12369.

2. Falkner, F. G., and Moss, B. (1990) Transient Dominant Selection of Recombinant Vaccinia Viruses. J. Virol. 64, 3108-3111.

3. Britton, P., Evans, S., Dove, B., Davies, M., Casais, R., and Cavanagh, D. (2005) Generation of a recombinant avian coronavirus infectious bronchitis virus using transient dominant selection. J. Virol. Meth. 123, 203-211.

4. Casais, R., Davies, M., Cavanagh, D., and Britton, P. (2005) Gene 5 of the avian coronavirus infectious bronchitis virus is not essential for replication. J. Virol. 79, 8065-8078.

5. Hodgson, T., Britton, P., and Cavanagh, D. (2006) Neither the RNA nor the proteins of open reading frames $3 \mathrm{a}$ and $3 \mathrm{~b}$ of the coronavirus infectious bronchitis virus are essential for replication. J. Virol. 80, 296-305.

6. Boulanger, D., Green, P., Smith, T., Czerny, C-P., and Skinner, M. A. (1998) The 131-amino-acid repeat region of the essential 39-kilodalton core protein of fowlpox virus FP9, equivalent to vaccinia virus $\mathrm{A} 4 \mathrm{~L}$ protein, is nonessential and highly immunogenic. J. Virol. 72, 170-179.

7. Mulligan, R., and Berg, P. (1981) Selection for animal cells that express the E. coli gene coding for xanthine-guanine phosphoribosyl transferase. Proc. Natl. Acad. Sci. USA 78, 2072-2076.

8. Britton, P., Green, P., Kottier, S., Mawditt, K. L., Pénzes, Z., Cavanagh, D., and Skinner, M. A. (1996) Expression of bacteriophage T7 RNA polymerase in avian and mammalian cells by a recombinant fowlpox virus. J. Gen. Virol. 77, 963-967.

9. Hiscox, J. A., Wurm, T., Wilson, L., Britton, P., Cavanagh, D., and Brooks, G. (2001) The coronavirus infectious bronchitis virus nucleoprotein localizes to the nucleolus. J. Virol. 75, 506-512.

10. Ausubel, F. M., Brent, R., Kingston, R. E., et al. (1987) Current Protocols in Molecular Biology. Wiley, New York.

11. Sambrook, J., Fritsch, E. F., and Maniatis, T. (1989) Molecular Cloning: A Laboratory Manual, 2 nd Ed. Cold Spring Harbor Laboratory, New York.

12. Mackett, M., Smith, G. L., and Moss, B. (1985) The construction and characterisation of vaccinia virus recombinants expressing foreign genes. In: Glover, D. M. (ed.) DNA Cloning: A practical Approach. IRL Press, Oxford, pp. 191-211.

13. Smith, G. L. (1993) Expression of genes by vaccinia virus vectors In: Davison, M. J., and Elliot, R. M. (eds.) Molecular Virology: A practical Approach. IRL Press, Oxford, pp. 257-83. 